stand, even now (supposing that Mr. Berlin's copy of my letter is correct), how the incorrect statement that the academy had bought such pipes, and paid such high prices for them, could have occurred unobserved. The boy who wrote the letter for me must have misunderstood me, and from my ignorance of the English language I overlooked this error. It may be, that, not attaching much importance to this letter, I may have sent it without first examining or looking it over.

In regard to the relics in question, it is impossible at present for me to determine whether those which $\mathrm{Mr}$. Stevens claims to have received from me are actually the objects which I have sent him; for I have not seen them as yet, and for the present shall have no opportunity, as Mr. Berlin has informed you that he could not send them for my inspection without the consent of Mr. Stevens. On the contrary, Mr. Stevens says that they no longer belong to him, but to Mr. Berlin.

Immediately on receiving your first communication on this matter, I resolved to send back to him the arrow-heads received in exchange, and to request him also to return those which he claimed were not genuine to me. Mr. Stevens returned the package to me, and refused to give me back those which he claimed I had sent to him, with the excuse that they were no longer in his possession, as he had given them to Mr. Berlin. Hence obviously it is impossible for me to determine as to the correctness of the statements made by those gentlemen concerning said relics. Their refusal to allow me to inspect the objects is very strange and perplexing to me.

As Mr. Stevens informs us that many of the relics I sent him were thrown out in the yard on a pile of other rejected relics, and have been lying there some years exposed to the weather, it is no wonder they became, as he says, considerably changed in appearance, and the labels lost. Under these circumstances, and after so long a time, it must have been very difficult for him to select the relics in question, and to distinguish them with certainty from those received from other sources in his extensive exchanges. I have no doubt, if I could see the relics, I should recognize many or most of them, unless they have been so changed by Mr. Stevens as to be no longer recognizable. Until this opportunity is afforded, the present account of the transaction must suffice.

That the intention or the thought of having any thing to do with doubtful relics, or of deceiving any one with them, was far from my mind, will, to you, scarcely require any special assurance from me.

Postville, Io., April 10.

J. GAss.

The above is a correct translation from the German of a communication written by Rev. J. Gass to Charles E. Putnam, Esq., hearing date April 10, 1886. Carl L. Suksdorf.

Davenport, Io., May 4. WM. KIEPE.

\section{What was the rose of Sharon?}

An interesting question is renewed, in a late number of the Edinburgh review, on ' What was the rose of Sharon?' It is very possible that some of the readers of Science may be able to throw further light upon the subject, or at least give trustworthy opinions as to the merits of 'crocus,' ' narcissus,' or
' reed.' The extract is, I hope, of sufficient interest to merit republication : it is as follows :-

"The 'rose of Sharon' has long been a disputed point. The Hebrew word khabatseleth occurs only in Canticles ii. 1, and Isa. xxxv. 1. The Revised version reads 'rose' in the text, and 'autumn crocus' in the margin. We are of opinion that the narcissus (N. tazetta) is intended. The scene of the Canticles is in the spring, when the narcissus would be in blossom: it is very sweet, has long been and still is a plant of which the orientals are passionately fond. Hasselquist noticed it on the plain of Sharon; Tristram, in cultivated land and lower hills from Gaza to Lebanon; Mr. H. Chichester Hart, in the districts between Yebdna and Jaffu (plain of Sharon). 'Some low-lying patches,' he says, 'were quite white with it.' The October quarterly statement (Palestine exploration fund) contains a valuable paper by Mr. C. Hart, entitled 'A naturalist's journey to Sinai, Petra, and South Palestine, made in the autumn of 1883.' The autumn crocus has no perfume, and would not be in bloom till late in the year. The narcissus is a bulbous plant, which is apparently implied in part of its Hebrew name; i.e., betsel (a 'bulb,' an 'onion'). But quite a different plant has very recently appeared as the claimant to the honor of being the 'rose of Sharon:' an Assyrian plant name is introduced to us by Dr. F. Delitzsch. Among the names of different kinds of kînû ('reed') and of objects made of it, occurring on a tablet in the British museum, and published in 'The cuneiform inscriptions of western Asia,' mention is made of one called khabatsillatu, which in sound is identical with the Hebrew name in Canticles and Isaiah; so that Dr. F. Delitzsch, without a moment's hesitation, upsets all other floral aspirants with one decided blow, and reads ' reed of Sharon,' 'the desert shall rejoice and sprout like the reed.'"

\section{Thermometer exposure and the contour of the earth's surface.}

Various writers during the last hundred years, and perhaps earlier, have called attention to the marked differences of temperature which are frequently to be found in clear weather between hill-tops and adjacent valieys. Recently Hann and Woeikof in Europe have written numerous papers on the subject; and in this country instances have been given by J. W. Chickering, jun., and S. Alexander (American meteorological journal), Professor Mendenhall (Science), Professor Hazen (Professional paper of the signal service, xviii.), and Prof. W. M. Davis ( $A p$ palachia). But attention has not generally been attracted to the bearing these differences of temperature have on the subject of thermometer exposure.

My attention was drawn to the subject by the marked differences of temperature which were reported by different observers at Ann Arbor, Mich., during the cold period of the winter of 1885 ; and, in order to study the subject, a regular series of observations were begun between the astronomical observatory at Ann Arbor and an adjacent valley through which ran the Huron River. The bottom of the valley was about a hundred and fifty feet lower than the land on each side of it, and was about a quarter of a mile distant from the side on which stood the observatory. The method employed was to obtain the temperature at the observatory by means of a sling thermometer; then descending the 